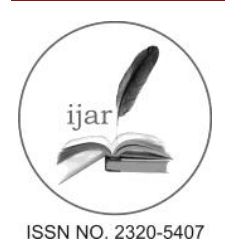

\author{
Journal homepage: http://www.journalijar.com

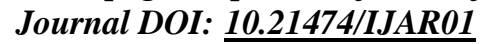

INTERNATIONAL JOURNAL

OF ADVANCED RESEARCH

RESEARCH ARTICLE

\title{
CRITICAL FACTORS AND DECISION VARIABLES AFFECTING QUALITY ASSURANCE AND RELIABILITY MANAGEMENT IN ROAD CONSTRUCTION PROJECTS IN NIGERIA.
}

\author{
Charles N. Ononuju, Uchenna U. Moneke, Stanley E. Okamgba. \\ Department ofPproject Management Technology, Federal University of Technology, P.M.B 1526, Owerri, Imo \\ State, Nigeria.
}

\section{Manuscript Info}

Manuscript History:

Received: 25 April 2016

Final Accepted: 19 May 2016

Published Online: June 2016

Key words:

Quality Assurance, Reliability

Management, Road Construction

Projects, Likert five point scales,

Multivariate Factor Analysis.

*Corresponding Author

Charles N. Ononuju.

\begin{abstract}
This study identified and analyzed quality assurance and reliability management (QARM) factors so as to provide ideas and techniques for ensuring that completed road projects perform their intended functions under stated operating conditions for a given period of time in Nigeria. The study adopted field survey and exploratory research designs with judgmental and quota sampling methods. Results of previous researches were used to identify the 25 main and 124 sub factors of QARM which were used to develop the questionnaire, modeled in Likert five point scale and a three weighted scoring model in the scales of 1,5 and 10 respectively. The method of data analysis was multivariate factor analysis. The results of the analyses indicated and isolated ten critical factors that are of decisive importance for the success of QARM in road construction projects. We concluded that ten most important factors determine the success rate of road construction and other construction projects in the South East Geopolitical Zone of Nigeria. This implies that these factors have greater impacts on quality assurance and reliability (QAR) in road construction projects.
\end{abstract}

Copy Right, IJAR, 2016,. All rights reserved.

\section{Introduction:-}

There is no gainsaying that the rate of failure of roads in Nigeria is worrisome. The situation is even worse in the south-eastern zone of the country, leading to concerns to both professionals and policy makers. A look at this scenario points to the problem of quality assurance and reliability (QAR) policy in the country's road infrastructural development.

A cursory survey reveals that the problem is a consequence of many factors which have not been properly identified and established, but hypothetically could be derived from procurement and construction practices adopted in the execution of the road projects. These factors individually and collectively contribute to the quality of the roads and their quality performance indices and reliability. Presently in construction project management, there is an abundance of tools and techniques available to measure and track project cost and schedule. But the same, however, cannot be said about project quality. Thus, while qualitative as well as quantitative measures of project cost and schedule performance are widely accepted and used, no similar measure currently exists for measuring project quality. Although quality metrics provides a quantitative measure of the degree to which the product of the project possesses and exhibits certain quality characteristics, "quality" is a relative term. The problem lies in the fact that quality changes with corresponding changes in the quality parameters. Quality parameters for roads include adherence or conformance to standards, error-free product, reliability, maintainability and correctness. However, no meticulous and integrated efforts have been made towards addressing and applying quality parameters in road construction projects through effective QAR management. These have resulted to the inability of completed road projects to perform their intended functions under stated operation conditions such as environment, geographical terrain, weather conditions and climatic seasons for a given period of time. The bane of successful road construction 
projects could be attributed to low level of QAR management, culminating to several concerns to the project managers such as unsatisfactory performance, bad image, low profitability, poor business results, loss of goodwill and confidence from clients, strained business relations, litigation, etc.

Because of the nature of soil and the prevalent high annual rainfall in the South-Eastern States of Nigeria, the issue of QAR of the roads has assumed the front burner among stakeholders, policy makers, contractors and researchers, who are desirous of effecting a change in the quality and performance of our roads. The deterioration of road infrastructure is a complex process which could be attributed to the interplay of a number of factors, including the following:

Pavement structure,

1. Construction material,

2. Traffic characteristics,

3. Weather condition, and

4. Environmental impact.

The non-existence of national standards on road construction as in other countries of the world has resulted in a general lack of uniformity among road agency acceptance plans, leading to the following situations:

* Use of acceptance plans that are totally ineffective,

* Severe difficulties in evaluating the effectiveness of some non-standard acceptance plans and,

* General dissatisfaction as evidenced by frequent haphazard revisions in agency's acceptance plans. These have a significant toll on QAR.

The objectives of this study are:

1. To identify the overall factors and decision variables affecting QAR management in road construction projects so as to take these into consideration in the formulation of quality policy;

2. To analyze and isolate the most critical factors affecting QAR management so as to pay special attention and exercise more control on them in the course of planning and execution of road construction projects;

It would help greatly if the acceptance plan designer had clear, specific, supported, and comprehensive guideline for developing acceptance plans based on best practices and verifiable empirical data. The guideline should also, where possible, take subjectivity out of acceptance plan design and replace it with rational and defensible scientific procedures.

\section{Literature review:-}

Quality is the summation of the following characteristics, right first time, value for money, customer satisfaction, consistent conformance to specification (Ameh et al. 2002). Excellence, conformance to standards or specifications, and fitness for purpose have all been criticized as definitions of quality (Dotchin and Oakland, 1993). Customers typically define quality as value or fitness for use, which involves expectations the customer has for the product (Garven 1983). Construction production quality is the degree to which the production meets the requirements and methodology stated in the design and specifications. The requirements refer to the needs or expectations of the client/promoters and the methodology implies execution of construction in conformity with the approved design, drawings and specifications. (Chitkara 2011). According to Mohammed et al. (2002), QA in the construction industry involves all activities and functions concerned with the attainment of quality and imply application of various management techniques. Quality assurance is a part of quality management focused on providing confidence that quality requirements will be fulfilled (ISO 9000, 2005). Gauri et al., (2015) and Chitkara (2011) outlined the differences between qc and QA. The content of a sound QA programme was enumerated by Olusola et al. (2002).tthe successful execution of a project on site is pinged on the ability of the contractor to forecast, plan and put in place the following monitoring and control documents: construction methodology/ programmes, project quality management manual, project health and safety plan, early warning systems chart and information requirement schedule ( Bamisile 2002). The inputs to project QA are listed by PMBOK 2013). The quality of any product (output) depends on two major factors, namely, input and the process of production (Nagarajan 2010).

According to Telsang (2010), customers always want that the products that are purchased should have a long service life and should give the intended service and utility with few failures. As the product becomes more complex, the problems of failures will increase over time. The improvement in the effectiveness of such complex systems has therefore acquired special importance in recent years. The effectiveness of a system is its suitability for the 
fulfillment of the intended function and the efficiency of utilizing the means put into it. The suitability for performing a definite task is primarily determined by the reliability of the system. An evaluation of the system's reliability becomes essential to decide whether a system will accomplish its mission successfully. When viewed from the economics and technical perspectives, the road infrastructure could be seen as both a product and a complex system.

In addition to impacting on the quality of work, QAR also has a significant impact on the project cost. This, on its part, depends on the quality of procurement method adopted for a given project. Traditional contracting specifications prescribe the materials, construction methods and the final deliverables for highway construction projects (Hancher, 1999).

Quality assurance and reliability (QAR) management in road construction projects have been studied and examined in isolation without taking into consideration, their interactive dependencies and interfaces. A quality assured constructed road project may not be reliable and vice versa. This study attempted to analyze and synthesize the factors of QAR management to achieve completed road construction projects that will ensure and satisfy both quality assurance and reliability requirements.

\section{Research methodology:-}

The following methodology was adopted in this research:

Table 1:- stages of the research.

\begin{tabular}{|l|l|}
\hline Stage & Research procedure \\
\hline 1 & Literature research to determine research focus \\
\hline 2 & Establish data sources of road construction projects \\
\hline $\mathbf{3}$ & $\begin{array}{r}\text { a) } \quad \text { Determine: i) local QAR factors } \\
\text { ii) QAR factors from literature }\end{array}$ \\
\hline 4 & $\begin{array}{r}\text { b) Prioritize principal QAR factors and sub-factors. } \\
\text { c) } \quad \text { Use the weighted average sum method on the sub-factors to identify the main factors. }\end{array}$ \\
\hline
\end{tabular}

The sources of data were the questionnaire, which sought to elicit information on QARM factors and construction practices adopted in road construction projects in a bid to properly examine QAR management. The data used for the study was obtained from the selected road construction firms executing various road construction projects in the south east geopolitical zone of Nigeria (SEGZN). The instruments of data collection and measurement were the questionnaire modeled in Likert five point scales and a three point scoring model. The questionnaire solicited the opinion of respondents on practices adopted in road construction projects as well as QAR management. The target respondents were stakeholders such as engineers, surveyors, consultants and project managers in the contracting companies and the clients' organizations such as the states'/federal ministries, agencies and departments and their staff involved in the execution of public works (state and local governments) in the SEGZN. The opinion expressed by each of the respondents is expected to be an expression of their experiences on previous as well as the specific projects they were presently executing. The process of the administration of the questionnaire was personal interview contact, which allowed for one-on-one approach in the asking and answering of the questions. Visits were made to 11 road construction project-based organizations and sites in the SEGZN.

\section{Questionnaire Design and Administration:-}

The questionnaire design was modeled in Likert five point scale.

The questionnaire consisted of three sections as follows:

Section 1: respondent's information

Section 2: ranking of the main factors of QAR by respondent

Section 3: ranking of the sub-factors of QAR by respondent.

The respondents were required to rank the main and sub-factors of QAR in road construction projects on a five point scale as follows:

1 represents very low important $=1$ point

Represents low important $=2$ points

Represents medium important $=3$ points 
Represents important, and $=4$ points

Represents very important $=5$ points

The questionnaire, which was the instrument of data collection, was administered to the technical experts who were involved in the execution of the selected road construction projects in the study area.

\section{Validation of the Instrument:-}

The questionnaire was reviewed by a group of experts in the field of study. They were requested to identify the internal validity and to what extent it was suitable for use as an instrument to realize the objectives of this research.

\section{Reliability of the Instrument:-}

Reliability of internal consistency was used to test the reliability of the questionnaire. The reliability coefficient of scale was established by Cronback's Alfa using SPSS package.

Methods of Data Analysis:-

The parameters of QARM management in road construction projects as obtained from literature review are as shown in table 2 were subjected to data collection and analyzed with the following methods.

Table 2:- QARM factors in road construction projects.

\begin{tabular}{|c|c|c|c|}
\hline S/no. & $\begin{array}{l}\text { Factor } \\
\text { code }\end{array}$ & QARM main factors & QARM subfactors \\
\hline 1. & $\mathrm{X}_{1}$ & Impact on road use & $\begin{array}{l}\text { Right use of completed road infrastructure } \\
\text { Traffic volume } \\
\text { Speed control bumps } \\
\text { Pavement unevenness } \\
\text { Potholes }\end{array}$ \\
\hline 2. & $\mathrm{X}_{2}$ & Climatic condition & $\begin{array}{l}\text { Heavy annual rainfall } \\
\text { Climate change } \\
\text { High temperature } \\
\text { Low temperature } \\
\text { Level of humidity }\end{array}$ \\
\hline 3. & $\mathrm{X}_{3}$ & Nature of contract agreement & $\begin{array}{l}\text { Cooperation between parties in the contract } \\
\text { Previous successful relations between parties } \\
\text { Clarity of conditions in a written contract } \\
\text { Use of standard contract } \\
\text { Method of award }\end{array}$ \\
\hline 4. & $\mathrm{X}_{4}$ & $\begin{array}{l}\text { Management } \quad \text { information } \\
\text { system }\end{array}$ & $\begin{array}{l}\text { Use of computer softwares and applications } \\
\text { Implimentation of qa/qc system } \\
\text { Use of cost control system } \\
\text { Use of time schedule } \\
\text { Existence and implementation of policies }\end{array}$ \\
\hline 5. & $\mathrm{X}_{5}$ & Construction process & $\begin{array}{l}\text { Use of contractor's preferred method } \\
\text { Use of client's preferred method } \\
\text { Availability of construction process information } \\
\text { Adoption of contractually agreed method } \\
\text { Supervision staff understanding of construction process }\end{array}$ \\
\hline 6. & $\mathrm{X}_{6}$ & Nature of project & $\begin{array}{l}\text { Scope of project } \\
\text { Type of project } \\
\text { Location of project } \\
\text { Site access } \\
\text { Duration of project }\end{array}$ \\
\hline 7. & $\mathrm{X}_{7}$ & $\begin{array}{l}\text { Reliability of pilot test of } \\
\text { subgrade }\end{array}$ & $\begin{array}{l}\text { Type of material } \\
\text { Nature of material } \\
\text { Bearing capacity of material } \\
\text { Moisture content } \\
\text { Confirmatory tests using independent laboratory }\end{array}$ \\
\hline
\end{tabular}




\begin{tabular}{|c|c|c|c|}
\hline 8. & $\mathrm{X}_{8}$ & Project monitoring and control & $\begin{array}{l}\text { Effective incoming inspection } \\
\text { Effective in-process supervision } \\
\text { Final inspection } \\
\text { Clear acceptance procedure } \\
\text { Clear procedure for rework } \\
\end{array}$ \\
\hline 9. & $\mathrm{X}_{9}$ & Environment impact & $\begin{array}{l}\text { Socio-economic environment } \\
\text { Stability of political environment } \\
\text { Youth restiveness/compensation issues } \\
\text { Land use/culture } \\
\text { Relation between construction and other industries }\end{array}$ \\
\hline 10. & $\mathrm{X}_{10}$ & Client's change request & $\begin{array}{l}\text { Presence of variation clause } \\
\text { Frequency of change request } \\
\text { Ease of obtaining approval } \\
\text { Client's emphasis on quality }\end{array}$ \\
\hline 11 & $\mathrm{X}_{11}$ & Efficiency of drainage system & $\begin{array}{l}\text { Adequate size } \\
\text { Drain type } \\
\text { Correct slope } \\
\text { Turf cover or dikes over embankment slope } \\
\text { Presence of runoff receptacle }\end{array}$ \\
\hline 12. & $\mathrm{X}_{12}$ & Quality of base course & $\begin{array}{l}\text { Type and nature of material } \\
\text { Nature of material } \\
\text { Moisture content } \\
\text { Bearing capacity } \\
\text { Confirmatory tests using independent laboratory } \\
\end{array}$ \\
\hline 13. & $\mathrm{X}_{13}$ & $\begin{array}{l}\text { Availability } \\
\text { skilled/unskilled labour }\end{array}$ & $\begin{array}{l}\text { Labour management system } \\
\text { Use of labour with high experience } \\
\text { Use of incentive schemes } \\
\text { Training programmes for labour } \\
\text { Remuneration for labour }\end{array}$ \\
\hline 14. & $\mathrm{X}_{14}$ & $\begin{array}{l}\text { Project execution and } \\
\text { implementation plan }\end{array}$ & $\begin{array}{l}\text { Use of integrated project execution system } \\
\text { Testing for final products only } \\
\text { Clear procedure for acceptance of work } \\
\text { Degree of importance attached to schedule } \\
\text { Preparing and using shop drawings }\end{array}$ \\
\hline 15 . & $\mathrm{X}_{15}$ & $\begin{array}{l}\text { Site staff/project } \\
\text { competence level }\end{array}$ & $\begin{array}{l}\text { Cooperation between client's and contractor's staff } \\
\text { Supervision staff's understanding of contract/project } \\
\text { management process } \\
\text { Skill and experience of supervision staff } \\
\text { Skill and experience of contractor's staff contractor staff } \\
\text { understanding of project management process }\end{array}$ \\
\hline 16 & $\mathrm{X}_{16}$ & Project funding plan & $\begin{array}{l}\text { Appropriate pricing of BEME } \\
\text { Amount of contractor's cash flow } \\
\text { Mobilization payment } \\
\text { Payment for interim certificate } \\
\text { Accuracy of BEME/realistic milestone breakdown }\end{array}$ \\
\hline 17. & $\mathrm{X}_{17}$ & $\begin{array}{l}\text { Level of compaction of } \\
\text { subbase }\end{array}$ & $\begin{array}{l}\text { Type and nature of material } \\
\text { Nature of material } \\
\text { Moisture content } \\
\text { Bearing capacity } \\
\text { Confirmatory tests using independent laboratory }\end{array}$ \\
\hline 18. & $\mathrm{X}_{18}$ & Subcontractors & $\begin{array}{l}\text { Procedure for selection of subcontractors } \\
\text { Strong cooperation between subcontractors and main } \\
\text { contractor } \\
\text { Use of a system for evaluation of subcontractor performance }\end{array}$ \\
\hline
\end{tabular}




\begin{tabular}{|c|c|c|c|}
\hline & & & $\begin{array}{l}\text { Skill and experience of subcontractor } \\
\text { Fair subcontract conditions }\end{array}$ \\
\hline 19 & $\mathrm{X}_{19}$ & Communication plan & $\begin{array}{l}\text { Effective communication between client and contractor } \\
\text { Modern communication technology } \\
\text { Availability of communication gadgets } \\
\text { Span of control } \\
\text { Effective communication between main contractor and } \\
\text { subcontractor }\end{array}$ \\
\hline 20. & $\mathrm{X}_{20}$ & Equipment capacity & $\begin{array}{l}\text { Availability of equipment } \\
\text { Equipment management system } \\
\text { Good utilization of equipment } \\
\text { Equipment maintenance } \\
\text { Equipment operator's skill }\end{array}$ \\
\hline 21 & $\mathrm{X}_{21}$ & Asphalt/product mix & $\begin{array}{l}\text { Use of binder/wearing course } \\
\text { Aggregate gradation } \\
\text { Adequacy of bitumen content } \\
\text { Effect of segregation/bleeding } \\
\text { Production/laying temperature } \\
\end{array}$ \\
\hline 22 & $\mathrm{X}_{22}$ & Site layout & $\begin{array}{l}\text { Spacious site layout } \\
\text { Well organized site layout } \\
\text { Clean site layout } \\
\text { Storage area for materials } \\
\text { Site has good access control } \\
\end{array}$ \\
\hline 23 & $\mathrm{X}_{23}$ & Materials management & $\begin{array}{l}\text { Using a comprehensive material management system } \\
\text { Cooperation between contractor and suppliers } \\
\text { Availability of good quality construction materials } \\
\text { Use of handling and storage system } \\
\text { Construction materials monopoly }\end{array}$ \\
\hline 24. & $\mathrm{X}_{24}$ & Quality of construction design & $\begin{array}{l}\text { Completeness, clarity and consistency of design documents } \\
\text { Degree of detailing of drawings } \\
\text { Conformance to codes and standards } \\
\text { Adherence to specifications } \\
\text { Accuracy and detailing of the bill of engineering measurement } \\
\text { and evaluation (BEME) }\end{array}$ \\
\hline 25 & $\mathrm{X}_{25}$ & $\begin{array}{l}\text { Government and professional } \\
\text { bodies regulation }\end{array}$ & $\begin{array}{l}\text { Adherence to codes of practice } \\
\text { Practice regulation by COREN/NSE } \\
\text { Training programmes by COREN/NSE } \\
\text { Adherence to laws } \\
\text { Effect of taxes }\end{array}$ \\
\hline
\end{tabular}

Sources: Ruston, and Amer, (2003), Ubani, (2012),

Return of Questionnaires:-

One hundred and ninety six (196) sets of questionnaires were distributed to the respondents while one hundred and eighty (180) were returned, representing $92 \%$ of the sample size. Therefore one hundred and eighty (180) of the respondents formed the basis of our presentation and analysis.

\section{Results:-}

The results of the factor analysis are presented below.

Component Grouping of the Twenty Five Identified Factors for Quality Assurance and Reliability inRroad Construction Projects:-

The factor analysis result in table 3 (rotated component matrix a) revealed that ten component factors loaded maximally which is agreed to be necessary for quality assurance and reliability in road construction projects. 
Table 3:- Rotated Component Matrix(a)

\begin{tabular}{|c|c|c|c|c|c|c|c|c|c|c|c|c|}
\hline & \multicolumn{10}{|c|}{ Raw } & & \\
\hline & \multicolumn{10}{|c|}{ Component } & \multicolumn{2}{|c|}{ Component } \\
\hline & 1 & 2 & 3 & 4 & 5 & 6 & 7 & 8 & 9 & 10 & 9 & 10 \\
\hline $\mathrm{X} 1$ & .264 & .311 & .759 & .835 & .779 & .973 & .548 & .598 & .013 & .177 & .003 & .039 \\
\hline $\mathrm{X} 2$ & .325 & .646 & .000 & .213 & .065 & .050 & .727 & .793 & .285 & .414 & .060 & .087 \\
\hline $\mathrm{X} 3$ & .838 & .023 & .915 & .766 & .239 & .055 & .453 & .381 & .179 & .034 & .045 & .009 \\
\hline $\mathrm{X} 4$ & .329 & .221 & .652 & .384 & .047 & .869 & .512 & .824 & .819 & .788 & .362 & .201 \\
\hline $\mathrm{X} 5$ & .767 & .708 & .603 & .202 & .564 & .047 & .617 & .895 & .844 & .965 & .599 & .310 \\
\hline X6 & .183 & .404 & .894 & .877 & .613 & .343 & .034 & .759 & .331 & .814 & .088 & .401 \\
\hline $\mathrm{X} 7$ & .405 & .770 & .626 & .402 & .845 & .763 & .650 & .684 & .756 & .824 & $\begin{array}{l}.350 \\
.212\end{array}$ & \\
\hline $\mathrm{X} 8$ & .234 & .962 & .750 & .119 & .130 & .663 & .479 & .117 & .172 & .175 & .040 & \\
\hline X9 & .033 & .033 & .694 & .018 & .266 & .455 & .753 & .111 & .042 & .262 & .012 & .075 \\
\hline X10 & .041 & .027 & .129 & .142 & .123 & .132 & .515 & .130 & .148 & .917 & .035 & .852 \\
\hline X11 & .496 & .661 & .281 & .736 & .754 & .790 & .948 & .498 & .571 & .897 & .128 & .335 \\
\hline X12 & .125 & .706 & .424 & .755 & .008 & .197 & .945 & .042 & .705 & .381 & .368 & .100 \\
\hline X13 & .152 & .643 & .279 & .560 & .104 & .472 & .762 & .093 & .219 & .054 & .057 & .014 \\
\hline X14 & .653 & .750 & .613 & .338 & .330 & .353 & .209 & .498 & .099 & .277 & .024 & .067 \\
\hline X15 & .844 & .300 & .423 & .055 & .897 & .103 & .142 & .363 & .829 & .044 & .222 & .012 \\
\hline X16 & .466 & .054 & .945 & .284 & .125 & .164 & .117 & .341 & .165 & .283 & .044 & .075 \\
\hline X17 & .387 & .754 & .402 & .324 & .142 & .010 & .376 & .183 & .893 & .588 & .677 & .148 \\
\hline X18 & .458 & .089 & .856 & .927 & .100 & .222 & .287 & .131 & .877 & .180 & .209 & .043 \\
\hline X19 & .328 & .040 & .822 & .153 & .386 & .062 & .818 & .469 & .583 & .765 & .139 & .270 \\
\hline X20 & .857 & .863 & .173 & .362 & .026 & .983 & .454 & .821 & .798 & .161 & .186 & .037 \\
\hline $\mathrm{X} 21$ & .285 & .558 & .365 & .230 & .113 & .925 & .860 & .254 & .072 & .727 & .016 & .163 \\
\hline X22 & .032 & .055 & .691 & .539 & .320 & .892 & .691 & .985 & .062 & .399 & .015 & .094 \\
\hline X23 & .924 & .027 & .985 & .034 & .106 & .646 & .470 & .748 & .407 & .355 & .099 & .087 \\
\hline X24 & .931 & .696 & .080 & .589 & .978 & .691 & .278 & .016 & .579 & .602 & .141 & .146 \\
\hline $\mathrm{X} 25$ & .131 & .182 & .488 & .102 & .958 & .412 & .394 & .175 & .560 & .205 & .137 & .050 \\
\hline
\end{tabular}

Extraction Method: Principal Component Analysis.

Rotation Method: Varimax with Kaiser Normalization.

A rotation converged in 15 iterations.

The principal factors include;

Component one:-

In the first principal component, the factor that loaded maximally is quality of construction design $\left(\mathbf{x}_{24}\right)$.

\section{Component two:-}

The variable that loaded maximally in component two is project monitoring and control $\left(\mathbf{x}_{\mathbf{8}}\right)$.

\section{Component three:-}

Materials management $\left(\mathbf{x}_{\mathbf{2 3}}\right)$ loaded maximally as the most significant factor.

\section{Component four:-}

Subcontractors' activities $\left(\mathbf{x}_{18}\right)$ loaded maximally at this stage as the most significant factor. 
Component five:-

Government and professional bodies regulations $\left(\mathbf{x}_{25}\right)$ is the most critical factor that loaded maximally in the fifth stage.

\section{Component six:-}

The variable that loaded maximally in component six is equipment capacity $\left(\mathbf{x}_{\mathbf{2 0}}\right)$.

\section{Component seven:-}

The variable that loaded maximally in component seven is efficiency of drainage system $\left(\mathbf{x}_{11}\right)$.

\section{Component eight:-}

The variable that loaded maximally in component eight is site layout $\left(\mathbf{x}_{\mathbf{2 2}}\right)$.

\section{Component nine:-}

The variable that loaded maximally in component nine is level of compaction of sub base $\left(\mathbf{x}_{17}\right)$.

\section{Component ten:-}

The variable that loaded maximally in component ten is construction process $\left(\mathbf{x}_{\mathbf{5}}\right)$.

These maximally loaded factors in each stage will be analyzed in subsequent study to determine their level of effects on the quality assurance and reliability of road construction projects in realizing time, cost and quality considerations of road project implementation.

Analysis of the identified factors based on the ten (10) components.

Table 4:- Total variance explained.

\begin{tabular}{|c|c|c|c|c|c|c|c|c|c|c|}
\hline & \multirow[t]{2}{*}{ Component } & \multicolumn{3}{|c|}{ Initial Eigen values(a) } & \multicolumn{3}{|c|}{$\begin{array}{l}\text { Extraction sums of squared } \\
\text { loadings }\end{array}$} & \multicolumn{3}{|c|}{ Rotation sums of squared loadings } \\
\hline & & Total & $\begin{array}{c}\% \text { of } \\
\text { variance }\end{array}$ & $\begin{array}{c}\text { Cumulative } \\
\%\end{array}$ & Total & $\begin{array}{c}\% \text { of } \\
\text { variance }\end{array}$ & $\begin{array}{c}\text { Cumulative } \\
\%\end{array}$ & Total & $\begin{array}{c}\% \text { of } \\
\text { variance }\end{array}$ & $\begin{array}{c}\text { Cumulative } \\
\%\end{array}$ \\
\hline \multirow[t]{25}{*}{ Raw } & 1 & 40.416 & 9.590 & 9.590 & 40.416 & 9.590 & 9.590 & 28.759 & 7.824 & 7.824 \\
\hline & 2 & 36.762 & 8.723 & 18.313 & 36.762 & 8.723 & 18.313 & 29.746 & 8.058 & 15.882 \\
\hline & 3 & 31.314 & 7.430 & 25.744 & 31.314 & 7.430 & 25.744 & 26.279 & 7.236 & 23.118 \\
\hline & 4 & 28.377 & 6.733 & 32.477 & 28.377 & 6.733 & 32.477 & 26.563 & 7.303 & 30.421 \\
\hline & 5 & 27.019 & 6.411 & 38.888 & 27.019 & 6.411 & 38.888 & 26.766 & 7.351 & 37.772 \\
\hline & 6 & 24.555 & 5.827 & 44.715 & 24.555 & 5.827 & 44.715 & 28.210 & 7.694 & 45.466 \\
\hline & 7 & 21.651 & 5.138 & 49.852 & 21.651 & 5.138 & 49.852 & 23.930 & 6.678 & 52.144 \\
\hline & 8 & 20.596 & 4.887 & 54.740 & 20.596 & 4.887 & 54.740 & 28.662 & 7.801 & 59.945 \\
\hline & 9 & 18.258 & 4.332 & 59.072 & 18.258 & 4.332 & 59.072 & 23.294 & 6.527 & 66.473 \\
\hline & 10 & 17.156 & 4.071 & 63.143 & 17.156 & 4.071 & 63.143 & 23.896 & 6.670 & 73.143 \\
\hline & 11 & 16.592 & 3.937 & 67.080 & & & & & & \\
\hline & 12 & 15.802 & 3.750 & 70.829 & & & & & & \\
\hline & 13 & 13.854 & 3.287 & 74.117 & & & & & & \\
\hline & 14 & 12.716 & 3.017 & 77.134 & & & & & & \\
\hline & 15 & 11.766 & 2.792 & 79.926 & & & & & & \\
\hline & 16 & 11.643 & 2.763 & 82.688 & & & & & & \\
\hline & 17 & 10.325 & 2.450 & 85.138 & & & & & & \\
\hline & 18 & 9.575 & 2.272 & 87.410 & & & & & & \\
\hline & 19 & 9.459 & 2.244 & 89.655 & & & & & & \\
\hline & 20 & 9.083 & 2.155 & 91.810 & & & & & & \\
\hline & 21 & 8.299 & 1.969 & 93.779 & & & & & & \\
\hline & 22 & 7.422 & 1.761 & 95.540 & & & & & & \\
\hline & 23 & 6.854 & 1.626 & 97.167 & & & & & & \\
\hline & 24 & 6.177 & 1.466 & 98.632 & & & & & & \\
\hline & 25 & 5.764 & 1.368 & 100.000 & & & & & & \\
\hline
\end{tabular}


Extraction method: principal component analysis.

a. when analyzing a covariance matrix, the initial eigenvalues are the same across the raw and rescaled solution.

The ten-component model generated normalized cumulative variance explanation of $73.143 \%$ as seen in the rotated sum of squares loadings above. The implication is that construction firms can achieve high quality assurance and reliability if these factors are analyzed and understood stage-by-stage as illustrated in table 4 above.

\section{Discussion of the findings:-}

The factor analysis loaded ten component factors maximally. Component 1 loaded quality of construction project design $\left(\mathrm{x}_{24}\right)$; component 2 loaded project monitoring and control $\left(\mathrm{x}_{8}\right)$; component 3 loaded materials management $\left(\mathrm{x}_{23}\right)$; component 4 loaded subcontractors' activities $\left(\mathrm{x}_{18}\right)$; component 5 loaded government and professional bodies' regulations $\left(\mathrm{x}_{25}\right)$; component 6 loaded equipment capacity $\left(\mathrm{x}_{20}\right)$; component 7 loaded efficiency of drainage system $\left(\mathrm{x}_{11}\right)$; component 8 loaded site layout $\left(\mathrm{x}_{22}\right)$; component 9 loaded level of compaction of sub base ( $\left.\mathrm{x}_{17}\right)$ while component 10 loaded construction process $\left(\mathrm{x}_{5}\right)$ maximally. We can therefore infer that the findings made in this study have to a large extent empirically justified the call for accurate and clear road project design, proper materials management, good equipment capacity, proper construction process, etc to eliminate incompetency, inexperience, corruption and other forms of indiscipline in the planning and implementation of road construction projects to ensure successfully accomplish the objective of meeting time, cost and quality considerations which are the main criteria of project success. These will also improve the provision of basic infrastructure needed for rural and national development.

However, in all the structure and machinery for road construction projects and other related projects, efforts at monitoring the above factors must not compromise the time and cost objectives, if actual success must be achieved that will trigger national development and actually complement the government efforts towards the achievement of millennium development goals (MDGs). It is our belief that national development for Nigeria will be realized if these findings are carefully considered and applied in designing and implementing road construction projects in Nigeria.

\section{Conclusion:-}

Based on the findings from the analyzed data, we concluded that ten most important factors determine the success rate of road construction projects and other construction projects in the South East Geopolitical Zone of Nigeria. The factors are quality of construction project design, project monitoring and control, materials management, subcontractors' activities, government and professional bodies' regulations, equipment capacity, efficiency of drainage system, site layout, level of compaction of sub base and construction process. This implies that these factors have greater impacts on QAR.

\section{References:-}

1. Ameh, o. J.; Odusami, K. T.; \& Ige, O. A. (2002). Assessment of effectiveness of quality assurance systems on building projects in lagos state. Proeedings of millennium conference on building in the $21^{\text {st }}$ century. Ahmadu Bello University, Zaria Department of Building, 234-247.

2. Bamisile, A. (2002). Building production management services. The unique role of builders. A paper presented at the annual conference of building students association, Obafemi Awolowo University, Ile-Ife.

3. Chitkara, K. K., (2011). Construction project management $2^{\text {nd }}$ ed: New Nelhi, Mcgraw Hill Education Private.

4. Dotchin, J. A. \& Oakland, j. S. (1993). Total quality management in services:part1. Quality and reliability management. 3, $9-26$.

5. Garvin, D.A. (1983). Quality on the line. Harvard business review, 61 (5), 64 - 75.

6. Gauri, S., Nikhilesh, J., Pooja, S., Amr ABD, E. \& Kate, T. (2015). Quality assurance vs quality control. Diffen.com. Diffen llc, http://www.diffen.com/difference/quality_assurance_vs_quality_control.

7. Hancher, D.E. (1999). Contracting methods for highway construction. Tranportation Research Board, National ResearchCcouncil, Washington, D.C.

8. ISO 9000 (1996). Quality management systems - fundamentals and vocabulary.

9. Krajewski, L.J. (1987). Operations management: strategy and analysis. Addison Wesley Longman Publishing Company.

10. Mohammed, S. N. \& Rotimi, J. O. (2002). A review of quality control and assurance in building construction, proc. Of millennium on building in the $21^{\text {st }}$ century, ABU, Zaira, Department of Building. 
11. Nagarajan, K. (2010). Project management, (5th ed.). New Delhi International Publishers.

12. Olusola, k. O., ayangade, J. A., \& Ata O. (2002). The role of builder in the achievement of building Provisions in nigeria. Proc. Of millennium conference on building in the $21^{\text {st }}$ century, ABU, Zaira.Department of Building.

13. PMBOK (2013). A Guide to the project management body of knowledge (5 $5^{\text {th }}$ ed.). Project management Institute, Pennsylvania USA.

14. Rustom, R., \& Amer, M. (2003). Identification of the factors affecting quality in building construction projects in Gaza Strip. In international conference on engineering and city development. 1, 89-101.

15. Telsang, M. (2010). Industrial engineering and production management. New Delhi: S.Chand and Company.

16. Ubani, e. C. (2012). Production and operations management - concepts, strategies and applications. Owerri:Ultimate Publishing Company. 